\title{
Family Business as a Career Opportunity for Women
}

Jaka Vadnjal, Blaž Zupan*

Abstract:

Women as managers and/or key people in family businesses are explored in this paper. Although recognized as generally very important players, the role of women is often defined as invisible in making important business decisions, supportive in traditionally men's business domains and is rarely adequately recognized and rewarded. Regardless, women find working for family businesses attractive and rewarding. We explore the differences in the views of men and women on issues in managing a small family-run business. Their attitudes on the roles of women, and general managerial and ownership issues, are surveyed. The findings support the paradigm of a feminine style of management and we pose the question whether businesses would be managed very differently if they were run by women.

Keywords: family business, women, gender roles, discrimination, managerial styles

JEL: L26

DOI: $10.2478 / v 10033-011-0013-z$

\section{Introduction}

The role of women as managers in family firms is missing proper observational recognition in the family business literature, as very few contributions were based on actual empirical research (Rowe \& Hong, 2000). Women as family members cultivate a high level of interest in their family's business, next to owners and employees (Davis \& Tagiuri, 1991). While women tend to enhance their presence as female entrepreneurs, research on women as family members in the field of family business suggested that a majority of women continued to remain in the background, staying "less visible" (Cole, 1997; Fitzgerald \& Muske, 2002). In just five years, from 2002 to 2007, the share of women occupying a CEO position in family businesses in the US grew by an astonishing 14 percentage points (Glavin, 2007) but still remains at low levels, with only $24 \%$ of all family businesses led by women. Another interesting observation is that family firms started adding "and Daughters" to their name in the 1990's, instead of "and Sons" (Gershick, 1997; Frieze \& Jacks, 1996). Occupying a subdued role, however, to some authors (Dumas, 1998;
Lyman et al., 1985) provided women with a unique vantage point for understanding the prevailing issues and relationship dynamics in family firms. Women used this insight to provide rare but valuable input into some managerial decisions and the management of relationships among family members (Sirmon \& Hitt, 2003). Moreover, a promising observation was made by Garcia Alvarez et al. (2002) who concluded that women as potential successors in family firms already are better educated than their male counterparts.

The main motivation to write this paper was to explore some particularities of women's contributions to family businesses by taking into account the paradigm of

\section{* Jaka Vadnjal \\ GEA College of Entrepreneurship, Slovenia \\ E-mail: jaka.vadnjal@gea-college.si}

\section{Blaž Zupan}

University of Ljubljana, Faculty of Economics, Slovenia E-mail: blaz.zupan@ef.uni-lj.si 
differences in managerial styles between men and women. First, the theory on women's involvement and roles in family businesses is outlined in the literature review. Next, based on the theoretical background, four propositions are presented and a methodological approach is outlined. Third, the results are discussed covering the managerial role of women and different gender-based roles in family firms. Finally, the paper is closed with conclusions and implications for further research.

\section{Literature Review}

Traditional gender roles are often present in family businesses. Walters (1982) suggested the prevalence of the dominant father figure and a subordinate mother figure throughout family businesses. Lyman et al. (1985) stated that the working environment in family businesses displays cultural traditions that place women, including wives, mothers, and daughters (Ponthieu \& Caudill, 1993) and men in different social positions and different work and family responsibilities. Evaluation of the real contribution of men and women to the family's economic well-being therefore includes a mix of paid employment and unpaid family work (Voydanoff, 1990), often unequally distributed between genders. A number of wives simultaneously (1) hold employment somewhere else, (2) manage a household, and (3) work in the family business, juggling three layers of obligation (Rowe \& Hong, 2000).

Involvement in a family business means being part of the family-business core structure: the role of family members in the business, how bonded the members are and how the business defines itself in relation to the outside world (Kellermanns et al., 2008). If a family member is not adequately recognized in running the business this creates dissatisfaction, tensions, and in the end clashes of values and beliefs about the operation of the business and the involvement, tasks and rewards for family members (Danes \& Amarapurkar, 2001; Frishkoff \& Brown, 1993). Prolonged and unresolved tensions may eventually have a destructive effect on the viability of family business and the health of family and business relationships (Danes et al., 2002). However, for Danes \& Olson (2003), tensions and conflicts can either foster a constructive climate that focuses resources on targeted goals, leading to growth and/or continued success (Cosier \& Harvey, 1998; Danes et al., 1999) or they can create an environment marked by a lack of trust and fellowship (Steier, 2001).

Some authors analyze the advantages and disadvantages for women in family firms (Frishkoff \& Brown, 1993), including flexible work hours, access to influential positions in traditionally male-dominated industries, job security, professional challenges, and opportunities for personal growth (Barnett \& Barnett, 1988). However, family firms can also involve gender stereotyping and discrimination like that found in society at large (Jaffee, 1990; Salganicoff, 1990), including the popular view that the male partner is the entrepreneur while the female partner does the bookkeeping in the back room (Dumas, 1998). This attitude leads to the fact that even important contributions from women to the family businesses will not be properly recognized in terms of job titles or salaries (Gillis-Donovan \& MoynihanBrandt, 1990; Lyman et al., 1985). Marshack (1994) found that $80 \%$ of male co-owners in husband-wife businesses advocated a stereotypical masculine gender-role orientation and $76 \%$ of female business co-owners supported a stereotypical feminine gender-role orientation. Women are seldom considered as successors in family businesses (Dumas, 1998; Haberman \& Danes, 2007), even more so in traditional societies where instead of daughters sons-in-law usually take over their spouse's family firm (Lee et al., 2003). Even in Western societies there is a history of choosing successors to family firms by subjective criteria, predominantly gender (Barnes, 1988); as for the UK, Martin (2001) concluded that not one appointed a female successor. On the other hand, Allen \& Langowitz (2003) found that companies managed by women are on average 10 years younger than those led by men but twice as productive. The entry of women to the leading positions in family businesses does have a multiplicative effect, as Barnes (1988) concludes that women serve as role models for other female family members who then consider family business an attractive career choice.

Gender roles in family firms are changing, but when a woman chooses a nontraditional role, tensions often surface (Freudenberger et al., 1989; Hollander \& Bukowitz, 1996; Lyman et al., 1996). As entrepreneurship has emerged as a career choice for both men and women, the choice has disrupted conservative traditions about worklife balance and family obligations (Greenhaus \& Callanan, 1994). As wives' influence in businesses clearly increases when they work within them (Wicker \& Burley, 1991), that relative influence can be a source of conflicting 


\begin{tabular}{|c|c|c|c|}
\hline Parameter & Number & Percent & Characteristics \\
\hline Business activity & $\begin{array}{r}37 \\
20 \\
19 \\
12 \\
8 \\
6 \\
3 \\
36\end{array}$ & $\begin{array}{r}34.5 \\
18.7 \\
17.8 \\
11.2 \\
7.5 \\
5.6 \\
2.8 \\
33.6\end{array}$ & $\begin{array}{l}\text { retail and wholesale trade } \\
\text { manufacturing } \\
\text { construction } \\
\text { transport and communications } \\
\text { other services } \\
\text { tourism and restaurants } \\
\text { financial and other services } \\
\text { other activities }\end{array}$ \\
\hline Legal status & $\begin{array}{l}62 \\
45\end{array}$ & $\begin{array}{l}57.9 \\
42.1\end{array}$ & $\begin{array}{l}\text { limited liability company } \\
\text { sole proprietors }\end{array}$ \\
\hline Number of employees & \multicolumn{2}{|c|}{ Average: 12.8} & \\
\hline $\begin{array}{l}\text { Number of family } \\
\text { members employed }\end{array}$ & \multicolumn{2}{|c|}{ Average: 2.67} & $\begin{array}{l}55(51.4 \%) \text { with two or less, } \\
52(48.6 \%) \text { with three and more }\end{array}$ \\
\hline Founders & $\begin{array}{r}63 \\
8 \\
23 \\
13\end{array}$ & $\begin{array}{r}58.9 \\
7.5 \\
21.5 \\
12.1\end{array}$ & $\begin{array}{l}\text { husband } \\
\text { wife } \\
\text { spouses as partners } \\
\text { others (businesses inherited) }\end{array}$ \\
\hline Foundation date & $\begin{array}{l}41 \\
50 \\
16\end{array}$ & $\begin{array}{l}38.2 \\
46.7 \\
15.0\end{array}$ & $\begin{array}{l}\text { before } 1989 \\
\text { during } 1990-1994 \\
\text { after } 1995\end{array}$ \\
\hline Family ownership & $\begin{array}{r}97 \\
9 \\
1\end{array}$ & $\begin{array}{r}90.7 \\
8.4 \\
0.9\end{array}$ & $\begin{array}{l}100 \% \text { family ownership } \\
50-81 \% \text { family ownership } \\
\text { no family ownership }\end{array}$ \\
\hline $\begin{array}{l}\text { Gender of the } \\
\text { manager }\end{array}$ & $\begin{array}{l}89 \\
18\end{array}$ & $\begin{array}{l}83.2 \\
16.8\end{array}$ & $\begin{array}{l}\text { Male } \\
\text { Female }\end{array}$ \\
\hline
\end{tabular}

Source: own sample, 2007

Table 1: Sample characteristics

perceptions and can create tensions for the family business (Rodriguez et al., 1999; Sharma, 2004).

Work-family issues at the intersection of business and family systems within family businesses are a particularly fertile area of conflict (Harvey \& Evans, 1994), with five sources of conflict: justice, role, work-family balance, identity, and succession conflict (Danes et al., 2000; McClendon \& Kadis, 1991). The existence of more than one decision maker in a family business will, in time, create some level of disagreement and tension (Kaye, 1996) fuelled by the different conflict resolution styles between men and women (Danes et al., 2000).

Poza \& Messer (2001) describe six different types of roles adopted by spouses of successful family firms: jealous spouse, chief trust officer, partner or co-preneur, vice-president, senior advisor, and free agent. Curimbaba (2002) reported that Brazilian women occupied either a professional, invisible, or anchor role in their firms. Due to the small convenience samples these studies mainly provide an indication of the varying types of women's roles. However, it is mostly expected from women to occupy the second rank or to head one of the business functions, traditionally finance and accounting or sales.

\section{Methodology, Propositions and Sample}

A sample of family firms was compiled from the public directory of all Slovenian SMEs. A random selection of 200 companies was made and asked through a phone call whether they considered themselves family businesses or not. Out of 200 companies, 107 explicitly confirmed themselves to be family businesses (Birley, 2001); we then used guided questionnaires to gather data. Certain criteria were put into place to be sure that firms have observable gender roles: (1) at least five employees, (2) at least two family members employed, (3) having been in business for a minimum of three years to have a certain 


\begin{tabular}{|c|c|c|c|c|c|}
\hline Group of respondents & $\begin{array}{l}\text { Number of } \\
\text { respondents }\end{array}$ & $\begin{array}{c}\text { Average age } \\
\text { (in years) }\end{array}$ & $\begin{array}{c}\text { Average work } \\
\text { experience (in } \\
\text { years) }\end{array}$ & $\begin{array}{c}\text { Work } \\
\text { experience in } \\
\text { other firms (in } \\
\text { years) }\end{array}$ & $\begin{array}{c}\text { Years in the } \\
\text { CEO role }\end{array}$ \\
\hline Managers: all & 107 & 47.2 & 25.6 & 10.2 & 14.2 \\
\hline - $\quad$ male CEOs & 89 & 48.2 & 26.8 & 10.5 & 14.9 \\
\hline - female CEOs & 18 & 42.6 & 19.4 & 8.7 & 10.3 \\
\hline Key women - all & 107 & 42.2 & 20.7 & 9.0 & \\
\hline Key non-CEO women & 89 & 42.1 & 20.9 & 9.1 & \\
\hline
\end{tabular}

Source: own sample, 2007

Table 2: Some age and experience related data on key groups of respondents

\begin{tabular}{|l|c|c|c|}
\hline \multirow{2}{*}{ School completed } & Founders of family firms (\%) & \multicolumn{2}{|c|}{ Managers (\%) } \\
\cline { 3 - 4 } & & All & Female \\
\hline Grammar school & 1.9 & 25.9 & - \\
Vocational school & 32.7 & 49.5 & 16.7 \\
Secondary school & 43.0 & 10.3 & 50.0 \\
College & 10.3 & 12.1 & 22.2 \\
University & 11.2 & 0.9 & 11.0 \\
Other & 0.9 & 107 & - \\
\hline Number of persons & 107 & 18 & \\
\hline
\end{tabular}

Source: own sample, 2007

Table 3: Level of formal education in the sample of family firms

track record and quite well established patterns of behavior.

The analysis of data is based on the following sections: (a) demographics on the family firm, (b) data on the manager, (c) data on the key woman in the firm (if she is not the $(E O)$.

Since this was one of the first studies on the role of women in family firms in Slovenia and it can be argued that findings from other countries would generally be applicable despite different histories, cultures and traditions of gender issues, four propositions were developed from the literature survey and some fragmented findings from past surveys:

P1. Women are underrepresented as CEOs compared to men in family firms but dominate in second-level managerial positions (Cole, 1997; Fitzgerald \& Muske, 2002).

P2. Women in family firms would exercise a different, softer style of management due to the differences in their values, personal traits and experience (Dumas, 1998; Poza \& Messer, 2004).

P3. Non-CEO women see many opportunities for improvements they would implement if they had a chance to run the family business (Frishkoff \& Brown, 1993; Barnett \& Barnett, 1988; Allen \& Langowitz, 2003).

P4. Although their contribution in the family firms is generally not adequately recognized, women still see many opportunities for themselves in family firms (Rowe \& Hong, 2000; Curimbaba, 2000; Barnes, 1988).

As presented in Table 1, family firms are mostly active in trade/retailing, but they are also reasonably represented in manufacturing and construction. Most companies were incorporated businesses and percentages are comparable with the official data of similarly sized companies in Slovenia.

On average, participating companies employed 12.8 employees. Approximately half of the sample (51.4\%) employed up to two family members, while the remainder employed at least three relatives. As expected, the vast majority of businesses were under the ownership control of the family, managed mostly by men in CEO positions (83.2\%) and only $15 \%$ of participating companies were in business twelve or fewer years, while the remaining companies were older. One particular family business with no family ownership was recently sold to a multinational holding company but family members still retained managerial positions. In the case of sole proprietors, only one member of the family actually owns the business, yet he or she can hire other members or outside employees. Some gender-based characteristics of the observed groups within the sample are given in Tables 2 and 3. As can be observed in Table 2, the women are on average younger than the men in the sample. There is no important difference between CEO women and key non-CEO women regarding age and years of experience. 


\begin{tabular}{|c|c|c|c|c|c|}
\hline \multirow{2}{*}{$\begin{array}{l}\text { Characteristics of behavior at } \\
\text { work }\end{array}$} & \multicolumn{3}{|c|}{ Managers } & \multirow{2}{*}{$\begin{array}{l}\text { All key } \\
\text { women }\end{array}$} & \multirow{2}{*}{ key Non-CEO women } \\
\hline & All & Men & Women & & \\
\hline Responsible & 5.37 & 5.33 & 5.61 & 5.27 & 5.20 \\
\hline \multirow[t]{2}{*}{ Pro-active } & 5.28 & 5.26 & 5.39 & 5.07 & 5.00 \\
\hline & & & & \multicolumn{2}{|c|}{$t=2.108 ; P=0.036$} \\
\hline Communicative & 5.19 & 5.13 & 5.44 & 5.09 & 5.01 \\
\hline \multirow[t]{2}{*}{ Persuasive, convincing } & 5.08 & 5.06 & 5.22 & 4.71 & 4.60 \\
\hline & & & & \multicolumn{2}{|c|}{$\mathrm{t}=3.247 ; \mathrm{P}=0.001$} \\
\hline \multirow[t]{2}{*}{ Good-hearted } & 5.05 & 4.97 & 5.44 & 5.28 & 5.25 \\
\hline & & \multicolumn{2}{|c|}{$t=1.883 ; P=0.062$} & \multicolumn{2}{|c|}{$\mathrm{t}=2.071 ; \mathrm{P}=0.040$} \\
\hline Efficient & 5.04 & 5.01 & 5.17 & 4.90 & 4.85 \\
\hline Sociable & 5.03 & \multirow{2}{*}{\multicolumn{2}{|c|}{$\begin{array}{cc}4.95 & 5.39 \\
t=1.757 ; P=0.082\end{array}$}} & 4.91 & 4.81 \\
\hline & & & & & \\
\hline Thorough, accurate & 5.03 & 5.00 & 5.17 & 5.15 & 5.14 \\
\hline \multirow[t]{2}{*}{ Pragmatic } & 4.99 & 4.91 & 5.41 & 4.75 & 4.62 \\
\hline & & \multicolumn{2}{|c|}{$t=2.189 ; P=0.031$} & \multicolumn{2}{|c|}{$t=2.087 ; P=0.038$} \\
\hline \multirow[t]{2}{*}{ Credible, trustful } & 4.92 & \multirow{2}{*}{\multicolumn{2}{|c|}{$\begin{array}{cc}4.83 & 5.33 \\
t=2.069 ; P=0.041\end{array}$}} & 4.93 & 4.85 \\
\hline & & & & & \\
\hline \multirow[t]{2}{*}{ Kind, pleasant } & 4.92 & \multirow{2}{*}{\multicolumn{2}{|c|}{$4.81 \quad 5.50$}} & 5.20 & 5.13 \\
\hline & & & & \multicolumn{2}{|c|}{$\mathrm{t}=2.348 ; \mathrm{P}=0.020$} \\
\hline Well organized & 4.92 & 4.88 & 5.11 & 4.83 & 4.77 \\
\hline Energetic & 4.86 & 4.80 & 5.17 & 4.71 & 4.61 \\
\hline Bright, lucid & 4.82 & 4.78 & 5.00 & 4.68 & 4.61 \\
\hline \multirow[t]{2}{*}{ Creative, full of ideas } & 4.80 & 4.82 & 4.72 & 4.38 & 4.31 \\
\hline & & & & \multicolumn{2}{|c|}{$t=3.503 ; P=0.001$} \\
\hline \multirow[t]{2}{*}{ Innovative } & 4.79 & 4.80 & 4.78 & 4.28 & 4.18 \\
\hline & & & & \multicolumn{2}{|c|}{$t=3.633 ; P=0.000$} \\
\hline \multirow[t]{2}{*}{ Benevolent } & 4.72 & 4.65 & 5.12 & 4.84 & 4.79 \\
\hline & & & $=0.072$ & & \\
\hline Enthusiastic & 4.68 & 4.66 & 4.78 & 4.56 & 4.51 \\
\hline Visionary & 4.55 & 4.65 & 4.06 & 3.96 & 3.94 \\
\hline & & & $=0.062$ & & $87 ; P=0.000$ \\
\hline Understanding & 4.52 & 4.43 & 5.00 & 4.86 & 4.83 \\
\hline & & & $=0.036$ & & $68 ; P=0.008$ \\
\hline Compassionate & 4.51 & 4.36 & 5.28 & 5.04 & 4.99 \\
\hline & & & $=0.001$ & & $52 ; P=0.000$ \\
\hline Generous & 4.47 & 4.35 & 5.06 & 4.69 & 4.61 \\
\hline & & & $=0.019$ & & \\
\hline Competitive & 3.75 & 3.89 & 3.06 & 3.21 & 3.24 \\
\hline & & & $=0.022$ & & $17 ; P=0.002$ \\
\hline Nervous & 3.32 & 3.40 & 2.89 & 3.29 & 3.38 \\
\hline Worried, not relaxed & 3.28 & 3.36 & 2.89 & 3.15 & 3.20 \\
\hline
\end{tabular}

Source: own sample, 2007

Table 4: Self-evaluation of work-related characteristics

A possible drawback of Slovenian family firms is the large share of these firms originating from the crafts sector, which had intensive development during the 1980 's with a more liberal economic policy. This crafts tradition provides a conservative view on some factors of success (Vadnjal \& Glas, 2008): education of the managerial staff, market orientation vs. product infatuation, acceptance of modern technology, etc. Having mostly first generation family firms in the sample, there is hardly any difference between the education of founders and the acting managers, as it is often expected in family businesses that the younger generations hold a higher level of formal education. On the other hand, as presented in Table 3, women in the sample tend to hold significantly higher levels of formal education than men $\left(X^{2}=11.64 ; D F=5 ; a=0.04\right)$.

\section{Women as Managers in Family Firms}

In some earlier work (Glas et al., 2006) the differences in life and work values among the generations were studied and the second generation was found to be more 


\begin{tabular}{|c|c|c|c|}
\hline $\begin{array}{l}\text { Statement about the change in management and doing business in the } \\
\text { family firm: As CEO, I would .... }\end{array}$ & $\begin{array}{l}\text { Strongly } \\
\text { agree }\end{array}$ & $\begin{array}{l}\text { Completely } \\
\text { agree }\end{array}$ & Mean value \\
\hline Improve the communication in the firm & 41 & 25 & 4.06 \\
\hline Work on improving the quality of products / services & 26 & 24 & 3.80 \\
\hline Give more support to the ambitions of employees & 43 & 13 & 3.77 \\
\hline Put more attention on teamwork & 41 & 12 & 3.67 \\
\hline Invest more in the education of the staff & 34 & 11 & 3.56 \\
\hline Make more relaxed, informal relationships in the firm & 29 & 16 & 3.54 \\
\hline Take care of higher wages/salaries of employees & 34 & 6 & 3.47 \\
\hline Provide more flexible employment for mothers employed & 32 & 10 & 3.46 \\
\hline Care more about the ethical side of the business & 32 & 6 & 3.28 \\
\hline Contribute more to charitable activities & 22 & 7 & 3.05 \\
\hline Make profit the key measure of success & 18 & 10 & 3.04 \\
\hline Enhance networking with other female entrepreneurs & 14 & 8 & 2.99 \\
\hline Rely more on external consultants & 23 & 5 & 2.98 \\
\hline Care more about community development & 13 & 4 & 2.93 \\
\hline Introduce more formal hierarchy - it should become clear who the boss is & 23 & 7 & 2.83 \\
\hline
\end{tabular}

Source: own sample, 2007

Table 5: Key women in the family firm on the changes in business in case they became CEOs

inclined towards the modern concept of a work-life balance. Looking at life and work values among gender specific groups in family firms, some differences were found as well (Vadnjal \& Zupan, 2009).

Work values confirm some of the expected characteristics of women that might influence their managerial styles, although few values are significantly different in terms of gender. More details on managerial styles can be found in the self-evaluation on the 25 characteristics of their behavior at work, using a 6-point Likert scale with 1 - Not true, to 6 - Completely true. The list of characteristics has been borrowed from research on Slovenian managers (Mihelic, 2006) that will enable further comparison beyond the scope of this article. In Table 4, these characteristics are ranked according to the average scores of all answers and added test results with the null hypothesis "There is no difference between both samples", where the difference between men and women managers was statistically significant at the $5 \%$ level $(\mathrm{P}<0.05)$

Our research (Table 4) has shown some patterns:

- highly ranked characteristics are a mixture of "hard" and "soft" traits

- female CEOs have generally evaluated themselves with the highest grade - this could be either explained by their over-confidence or by the assumption that they really have to be superior to men to climb to the top position

- the exceptions to this pattern are few but interesting: male CEOs should be more creative and innovative, they are superior in creating visions and they behave in a more competitive way; however, they also act more nervously and worriedly, which might put them under stress and has a negative impact on their well-being

- non-CEO women fall significantly behind the female CEOs but also behind male CEOs, with the exception of some highly "feminine" characteristics: they are more good-hearted, credible and trustful, kind, benevolent, understanding, compassionate and generous; it could be also added that they are more thorough as an assumed trait of women

These results confirm the assumption that the "female" managerial style would differ from that of male CEOs. Female CEOs seem to be a rather select group, and not like other women; again, either as a result of the duties and challenges they faced at the top or the very selective process that demands that they be superior to men to be trusted as CEOs. The ultimate mark of different managerial styles is presented by the statements of nonCEO women about what they would change in the way of managing and running the family firm if they became CEOs on the 5-point Likert scale. In Table 5, the number of non-CEO key women are provided that certainly agree with the changes ( $4=$ strongly agree and $5=$ completely agree) and the mean value. 


\begin{tabular}{|l|c|c|}
\hline \multicolumn{1}{|c|}{ Assumed advantages of working in family firms } & \multicolumn{2}{c|}{ Key non-CEO women } \\
\cline { 2 - 3 } & \multicolumn{2}{c|}{ Mean } \\
\hline More autonomy at work & 4.18 & 1 \\
\hline Having more flexible working time & 4.16 & $2-3$ \\
\hline Having more control over duties, obligations & 4.16 & $2-3$ \\
\hline Being more equal with men & 3.92 & 5 \\
\hline Being more satisfied with life & 3.90 & 3.82 \\
\hline Being less exposed to bullying & 3.82 \\
\hline Getting a better salary & 3.65 & 7 \\
\hline My work is more appreciated, recognized & 3.43 \\
\hline Having more time for family & 3.27 & 8 \\
\hline
\end{tabular}

Source: own sample, 2007

Table 6: The advantages of being employed by family firms (mean values)

Women would exercise change in many aspects of management:

- their focus would be on communication in the firm, quality of products/services, support for employees' ambitions and teamwork - this quality is already a high level of concern of family firms according to our survey and other research on family firms in Slovenia, while the other three items seem quite "feminine."

- there would be more attention on the education of employees, more informal and relaxed relationships (women are the proponents of such an approach since they least support more formal hierarchy)

- there is no high priority given to provide more work flexibility for employed mothers which might disappoint, if firms have not already done a lot in this respect.

- women would not seek support from other female entrepreneurs - they do not stress gender and they feel quite self-confident in the broader entrepreneurial community - this finding supports the practice in Slovenia, where women rarely make separate groups and do not stress the gender aspect in creating networks, but strive to become an equal part of broader networks;

- women would care for the ethical aspect of business, but there is no intensive focus given to the social responsibility of the business, charity or community development, which is partly surprising.

The findings do not give a very high level of support to the proposition of a significantly different approach by women to management and business issues. This approach is marked more by the general situation of entrepreneurship in Slovenia, where the culture, overall business climate and government policies are not perceived as business-friendly. Gender is not the prime concern, and women would not forge "a revolution" in firms if they became CEOs.

\section{Family Firm: A Career Opportunity for Women?}

It has been found that women's contributions to the family firm are not really recognized and rewarded, and that they would also change a number of issues in the formal structure of family firms, including their management style and the climate among employees. However, women who did not decide to pursue a CEO position or were not appointed as successors in their family's firm, and therefore have or had a realistic chance to be employed elsewhere, still find a number of advantages in being employed in the family firm as compared to non-family firms. This view is shared also by women entrepreneurs who prefer the challenges of an entrepreneurial career. All key non-CEO women were asked to assess the potential advantages on a 5-point Likert scale. Women were very affirmative in assessing the advantages of family firms, mostly related to enhanced autonomy and flexibility, while financial advantages were not really confirmed (Table 6).

Non-CEO women feel more equal to men since they mostly perform meaningful duties in the firm. However, this fact also means that they share more responsibilities in the firm and possibly do not have time for family. Due to their role in the firm, key non-CEO women have assessed these advantages as relatively high. Family firms that are on average still fairly small mostly do not offer good formal career prospects, while they allow women more control over their work and relationships. 


\section{Conclusions and Implications}

Considering the number of family firms in Slovenia, more women are taking part in the entrepreneurial potential of these firms than starting their own businesses. Working with family members and avoiding stress and uncertainty by leaving the leadership role to their male partners seems more attractive to women than facing business challenges as sole owners. On the other hand, while the informal role of women is often recognized, such a role is more pronounced in family firms. In the latter, women exercise their influence on the decision-making process in the office and during family time.

Considering that female family members share second-rank managerial roles in a large share of family businesses where men dominate as CEOs, their share in ownership certainly understates their role in running the family business. However, women do not seem opposed to the existing situation, and often consider their informal influence as powerful enough to provide them personal satisfaction. They also do not opt for higher salaries and benefits, although this aspect may become important with the reform of the health and pension systems, which would relocate the access to services increasingly towards the voluntary involvement of beneficiaries. Women rather deny these financial aspects as important and this denial is a good cause not to push for changes. All this is supported by the first proposition, which can be regarded as supported.

The "feminine" style of women in family firms is very important for creating good internal relationships, the overall climate in business, and employee satisfaction and morale. This aspect is likely to positively contribute to the financial performance of family firms, but it has value in itself for the well-being of employees even if it does not materialize in improved balance sheets. This contribution by women is often benevolently recognized but not adequately rewarded. Again, women are quite patiently wishful for social recognition and the recognition of their family members, but they do not intensely pursue their demands. Thus, it can be concluded that data from the study confirm the third proposition, which suggests that women often possess different views on transitional issues compared to men. Interestingly, this confirmation is stricter for female respondents, which may be interpreted such that women are more aware of their gender dictated managerial roles.
Women, when becoming CEOs, would introduce a number of changes in the management style, where they would add their softer feminine approach as a new quality to the existing style. This assumption is very relativistic, since the research has indicated that female CEOs behave unlike other female family members involved in the firm. These findings contribute to the confirmation of proposition three. It can be said that women in family firms need to be very tough and superior to their male siblings in order to get to the top position. The process of their elevation to the CEO position can neutralize part of their femininity and softness, and performing the duties of a CEO seems to develop experiences that harden their approaches. Taking into account all of the abovementioned findings, proposition three can be neither confirmed nor rejected.

For the purpose of managing small family firms and also consulting for them, it should be clear that women's roles in the family business are often formally underestimated. Women not only play a traditional supportive and invisible role but can also contribute to a different, people-oriented managerial style when their feminine style of tackling business issues is applied as an alternative to the more traditional masculine approach. In diagnosis processes of consulting projects, women, although not holding leadership positions, may be invaluable sources of information and complementary opinions. In conflict resolution programs, women can play an enormously positive role in lowering the temperature which usually rises among men.

There are many opportunities for further research in the field. Researchers should be encouraged to start longitudinal multinational studies in order to assess differences between countries and cultures. A more multi-disciplinary approach is recommended because the complex family and partnership relationship combined with the pressures of daily business activities demands much broader research skills and knowledge than is usually available and provided by business science researchers. An insight on the work-life balance of women in family businesses would give valuable insight for further policy measures and recommendations. $[$.

\section{References}

Allen, I. E., \& Langowitz, N. S. (2003)," Women in family owned businesses", Boston, MA: MassMutual \& Center of Women's Leadership, Babson College.

Barnes, L. (1988), "Incongruent hierarchies: Daughters and younger sons as company CEOs", Family Business Review, 1 (1), pp. 9-21. 
Barnett, F., Barnett, S. (1988), "Working together: Entrepreneurial couples", Berkeley, CA: Ten Speed Press.

Birley, S. (2001), "Owner-Manager attitudes to family and business issues: A 16 country study", Entrepreneurship Theory and Practice, 26 (2), pp. 221-235.

Cole, P. M. (1997), "Women in family business", Family Business Review, 10 (4), pp. 353-371.

Cosier, R. A., \& Harvey, M. (1998), "The hidden strengths in family business: Functional conflict", Family Business Review 11 (1), pp. 75-79.

Curimbaba, F. (2002), "The dynamics of women's roles as family business managers", Family Business Review 15 (3), pp. 239-246.

Danes, S. M., Leichtentritt, R., Metz, M. E., \& Huddleston-Casas, C. (2000), "Effects of conflict styles and conflict severity", Journal of Family and Economic Issues 21 (3), pp. 259-286.

Danes, S. M., Zuiker, V. S., Kean, R., \& Arbuthnot J. (1999), “Predictors of family business tensions and goal achievement", Family Business Review, 12 (3), pp. 241-252

Danes, S. M., \& Amarapurkar, S. (2001), "Business tensions and success in farm family businesses", Family Economics and Resource Management Biennial, 4, pp. 178-190.

Danes, S. M., Reuter, M. A., Kwon, H. K., \& Doherty, W. (2002), "Family FIRO model: An application to family business", Family Business Review, 15 (1), pp. 31-43.

Danes, S. M., \& Olson, P. D. (2003), "Women's role involvement in family businesses, business tensions, and business success", Family Business Review, 16 (1), pp. 53-68.

Davis, J., \& Tagiuri, R. (1991), "Bivalent attributes of the family firm", In: C. E. Aronoff, J. L. Ward (Eds): Family business sourcebook: A guide for families who own businesses and the professionals who serve them. Detroit, Ml: Omnigraphics: pp. 62-73.

Dumas, C. (1998), "Women's pathways to participation and leadership in the family-owned Firm", Family Business Review, 11 (3), pp. 219-228.

Fitzgerald, M. A., \& Muske, G. (2002), "Copreneurs: An exploration and comparison to other family businesses", Family Business Review, 15 (1), pp. 1-16.

Freudenberger, H. J., Freedheim, D. K., \& Kurtz, T. S. (1989), "Treatment of individuals in family business", Psychotherapy, 26 (1), pp. 47-53.

Frieze, S. B., \& Jacks, J. R. (1996), "Creating a successful succession", The Secured Lender, 52 (5), pp. 38-42.

Frishkoff, P., Brown, B. (1993), "Women on the move in family business", Business Horizons, 36 (2), pp. 66-70.

Garcia Alvarez, E., Lopez-Sintas, J. \& Saldana-Gonzalvo, P. (2002), "Socialization patterns of successors in first to second-generation family businesses", Family Business Review, 15 (3), pp. 189-203.

Gillis-Donovan J., C. Moynihan-Brandt. (1990), "The power of invisible women in the family business", Family Business Review, 3 (2), pp. 153-167.

Glas, M., J. Herle, F. Lovsin Kozina, J. Vadnjal. (2006), “The state of the family firm management in Slovenia", Paper presented at 2nd Workshop on Family Firm Management Research, Nice, 1-2 June 2006.

Glavin, B., Astrachan, J., \& Green, J. (2007), “American family business survey", MassMutual; Cox Family Enterprise Center, Coles College of Business, Kennesaw State University; The Family Firm Institute, Inc.

Greenhaus, J. H., \& Callanan, G. A. (1994), “Career management (2nd ed.)", Ft. Worth: Dryden Press.

Haberman, H., \& Danes, S.M. (2007), "Father-daughter and fatherson family business management transfer comparison: Family FIRO model application", Family Business Review, 20 (2), pp. 163-185.
Harvey, M. R., \& Evans, E. (1994), "Family business and multiple levels of conflict", Family Business Review, 7 (4), pp. 331-348.

Hollander, B. S., \& Bukowitz, W. R. (1996), "Women, family culture and family Business", In C. E. Aronoff, J. H Astrachan, J. L. Ward (Eds.): Family and Business. Sourcebook II. Marietta, GA: Business Resources, pp. 451-459.

Jaffee, D. T. (1990), "Working with the ones you love: Conflict resolution \& problem solving strategies for a successful family business", Berkeley: Conari Press.

Kaye, K. (1996), "When the family business is a sickness", Family Business Review, 9 (4), pp. 347-368.

Kellermanns, F. W., Eddleston, K., Barnett, T., \& Pearsnon, A. (2008), "Family member characteristics and involvement: Effect on entrepreneurial behavior in the family firm", Family Business Review, 21 (1), pp. 1-14.

Lee, K.S., Lim, G.H. \& Lim, \& W.S. (2003), "Family business succession: Appropriation risk and choice of successor", Academy of Management Review, 28 (4), pp. 657-666.

Lyman A., Salganicoff, M., \& Hollander, B. (1985), "Women in family business: An untapped resource" in C. E. Aronoff, J. L. Ward (Eds.): Family business sourcebook. Detroit: Omnigraphics, pp. 46-49.

Lyman A., Salganicoff, M., \& Hollander, B. (1996), "Women in family business: An untapped resource" in C. E. Aronoff, J. H. Astrachan, J. L. Ward (Eds.): Family and business sourcebook II. Marietta, GA: Business Resources, pp. 460-463.

Marshack, K. J. (1994), "Copreneurs and dual-career couples: Are they different?", Entrepreneurship Theory and Practice, 19 (1), pp. 49-69.

Martin, L. (2001), "More jobs for the boys? Succession planning in SMEs", Women in Management Review, 16 (5), pp. 222-231.

McClendon, R. \& Kadis, L. B. (1991), "Family therapists and family businesses: A View to the future", Contemporary Family Therapy, 13 (6), pp. 641-651.

Mihelic, K. (2006), "Vrednote slovenskih managerjev ob vstopu v 21. Stoletje", Magistrsko delo. Ljubljana: Ekonomska fakulteta.

Ponthieu, L. D., \& Caudill, H. L. (1993), "Who's the boss? Responsibility and decision making in copreneurial ventures", Family Business Review, 6 (1), pp. 3-17.

Poza, E. J., \& Messer, T. (2001), "Spousal leadership and continuity in the family firm", Family Business Review, 14 (1), pp. 25-36.

Rodriguez, S. N., Hildreth, G. J., \& Mancuso, J. (1999), "The dynamics of families in business: How therapists can help in ways consultants don't", Contemporary Family Therapy, 21 (4), pp. 453-468.

Rowe, B. R., \& Hong, G. S. (2000), "The role of wives in family business: the paid and unpaid work of women", Family Business Review, 13 (1), pp. 1-13.

Salganicoff, M. (1990), "Women in family business: Challenges and Opportunities", Family Business Review 3 (2), pp. 125-138.

Sharma, P. (2004), "An overview of the field of family business studies: Current status and directions for the future", Family Business Review, 17 (1), pp. 1-36.

Steier, L. P. (2001), "Family firms, plural forms of governance, and the evolving role of trust", Family Business Review, 14 (4), pp. 353-368.

Vadnjal, J., \& Zupan, B. (2009), "The role of women in family businesses", Economic and Business Review, 11 (2), pp. 159-177.

Vadnjal, J., \& Glas, M. (2008), "Transgenerational entrepreneurial attitudes in family businesses in a transition economy" in V. Gupta, N. Levenburg, L. L Moore, J. Motwani, T. V. Schwarz, (Eds.): Culturallysensitive Models of Family Business in Eastern Europe: A Compendium Using the GLOBE Paradigm. Hyderabad: The Icfai University Press, pp. 23-48. 
Voydanoff, P. (1990), "Economic distress and family relations: A review of the eighties". Journal of Marriage and the Family, 52 (4), pp. 1099-1115.

Walters, L. H. (1982), "Are families different from other groups?", Journal of Marriage and the Family, 44 (4), pp. 841-850.

Wicker, A. W., \& Burley, K. A. (1991), "Close coupling in work-family relationships: Making and implementing decisions in a new family business and at home", Human Relations, 44 (1), pp. 77-92. 